\title{
Cell adhesion molecules and their possible role in the pathology of the peripheral nerves - a review of the literature
}

\author{
Cząsteczki adhezji komórkowej i ich rola w patologii nerwów obwodowych \\ - przegląd literatury
}

ADAM NIEZGODA A, B, D-F

Department of Neurology, University of Medical Sciences of Poznan

A - Study Design, B - Data Collection, C - Statistical Analysis, D - Data Interpretation, E - Manuscript Preparation, $\mathbf{F}$ - Literature Search, $\mathbf{G}$ - Funds Collection

Summary Cell adhesion molecules (CAMs) are glycoproteins uniformly present on the cell surface. They are responsible for cell-to-cell and cell-to-extracellular environment interactions such as adhesion, growth, migration. They are expressed on the surface of the immune cells and take part in various inflammatory events. CAMs are divided into four groups: immunoglobulin superfamily, selectins, cadherins and integrins. They all share the same structure: CAMs are composed of three fragments - extracellular domain responsible for receiving signals from the extracellular space, transmembrane fragment and intracellular part which interacts with cytoskeleton. CAMs are present on cell-membrane in their native original cell-bound forms which may be released to body fluids as circulating or soluble forms. The soluble forms likely have the same potential of binding to their natural counterparts as the native forms. It is generally admitted that increased concentration of the soluble form reflects its overexpression on the cell surface. We hypothesized that the soluble forms could be a sort of truncated false saturators for their natural counterpart which finally reduce the triggered inflammatory cascade. They should be then considered a self-limiting negative feed-back mechanism of the CAM-activated inflammatory pathway. We present current data on the possible involvement of CAMS in various human pathologies with special emphasis on the diseases of the nervous system.

Key words: cell adhesion molecules, demyelination, polyneuropathies.

Streszczenie Cząsteczki adhezji komórkowej (cell adhesion molecules, CAMs) są glikoproteinami obecnymi na powierzchni wszystkich komórek. Odpowiedzialne są za interakcje ze środowiskiem zewnętrznym, za procesy takie, jak przyleganie, wzrost, migracja. CAMs występują również na powierzchni komórek układu immunologicznego i są zaangażowane w różne procesy odpornościowe. CAMs dzielone są na cztery grupy: nadrodzinę immunoglobulin, selektyny, cadheryny oraz integryny. Wszystkie CAMs mają tę samą budowę: składają się z fragmentu zewnątrzkomórkowego odpowiedzialnego za kontakt z otoczeniem oraz przyjmowaniem sygnałów z zewnątrz do komórki, fragmentu przezbłonowego oraz części wewnątrzkomórkowej - odpowiedzialnej za kontakt błony z cytoskeletonem. CAMs występują w dwóch postaciach: w formie natywnej związanej z błoną komórkową, która może zostać „złuszczona” do środowiska otaczającego i stać się postacią „rozpuszczalną". Uważa się, że postaci rozpuszczalne mają zdolność wiązania się z tymi samymi partnerami, co postaci natywne. Uważa się, że wzrost stężenia postaci rozpuszczalnych CAMs jest spowodowany wzrostem ekspresji postaci natywnych na powierzchni komórek. Wysuwamy hipotezę, że obecność w płynach ustrojowych postaci rozpuszczalnych jest formą mechanizmu samoograniczającego skutki interakcji CAMs z ich naturalnymi ligandami, ponieważ postaci rozpuszczalne działają jak swoisty kompetytywny bloker receptora (ligandu) postaci natywnej, dla której stają się w tym momencie konkurencją. Przedstawiamy aktualny stan wiedzy na temat udziału CAMs w patologii człowieka ze szczególnym uwzględnieniem chorób układu nerwowego.

Słowa kluczowe: demielinizacja, cząsteczki adhezji komórkowej, polineuropatie.

Fam Med Prim Care Rev 2015; 17(4): 323-326

\section{Background}

Cell adhesion molecules (CAMs) are cell membrane glycoproteins that assure cell-to-cell or cell-to-extracellular matrix interactions. CAMs are thought to be necessary for cell growth, outgrowth, migration; in the nervous system they are involved in the neuronal network formation as well as synaptic plasticity. CAMs are also widely present on cells of the immune system and participate in immune mediated reactions. In this article we will present the possible role of the CAMS in the pathomechanism of the peripheral nerve affections with special emphasis on polyneuropathies.

All CAMs have common general structure: they are composed of three portions (Fig. 1):

- intracellular domain that interacts with cytoskeleton,
- transmembrane portion,

- extracellular fragment which may interact with the same counterpart (homophilic reaction) or a different partner (heterophilic reaction).

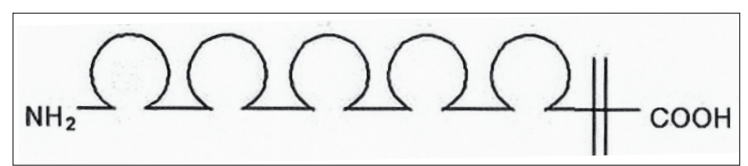

Figure 1. Example of cell adhesion molecule structure - ICAM-1 $\mathrm{NH}_{2}$ - extracellular terminal, $\mathrm{COOH}$ - intracellular terminal, rings correspond to immunoglobulin (Ig) - like domains

Adhesion molecules are commonly divided into four different groups: 
1) immunoglobulin superfamily - capable of homophilic or heterophilic interactions with other immunoglobulin superfamily members or integrins; they are characterized by Ig-like transmembrane domains; most known examples are:

- vascular cell adhesion molecule (VCAM or CD106), intercellular adhesion molecule (ICAM or CD54), platelet-endothelial cell adhesion molecule (PECAM or CD31); the isoforms of CAMS which may differ in number of the Ig-like transmembrane domains are numbered (e.g. ICAM-1, ICAM-2, ICAM-3 etc);

- ICAM-1 is found e.g. on endothelial cells or on immune cells and its counterpart is leucocyte function antigen LFA-1 - an integrin receptor found on leukocytes;

- $\quad$ VCAM-1 is present on all leukocytes and its natural counterpart is the Very Late Antigen (VLA-4) which is an integrin of the $\beta-1$ subfamily;

- PECAM-1 is mainly present on platelets and endothelial cells, it is thought to interact mainly with another PECAM-1 (homophilic reaction);

2) selectins - responsible for heterophilic binding of cell to environmental fucosylated extracellular matrix carbohydrates; most known are endothelial (or E)-selectin, platelet (or P)-selectin, leucocyte (or L)-selectin); the natural ligand for them is P-selectin glycoprotein ligand-1 (PSGL-1);

3) cadherins - concentrated at cell junctions, they bind the actin filament network;

4) integrins - they mediate cell-extracellular matrix linking e.g. with proteins like fibrinogen, collagen, fibronectin or with immunoglobulin superfamily counterparts.

\section{Cell adhesion molecule - forms, timing, role}

CAMs are present on cell-membrane in their native original cell-bound forms which may be released to body fluids as circulating (c) or soluble (s) forms. It is believed that the soluble forms have the same potential of binding to their natural counterparts as the native forms. There is controversy about the physiological role of the soluble forms of CAMs. It is generally admitted that increased concentration of the soluble form reflects its overexpression on the cell surface. Binding of the cell-bound form of a CAM e.g. on a leukocyte with its endothelial counterpart may trigger events like rolling of the leukocyte on the endothelium, then adhesion to it and finally leucocyte transmigration to the inflammatory site (Fig. 2).

It is also generally believed that increased levels of soluble forms of CAMS contribute directly to activation of the immune processes. Because the native and soluble forms may have opposite effects [1, 2]. Niezgoda and Losy hypothesized that the soluble forms are rather a sort of truncated false satu- rators for their natural counterpart which finally reduce the triggered inflammatory cascade $[1,8]$. They should be then considered a self-limiting negative feed-back mechanism of the CAM-activated inflammatory pathway (Fig. 3).

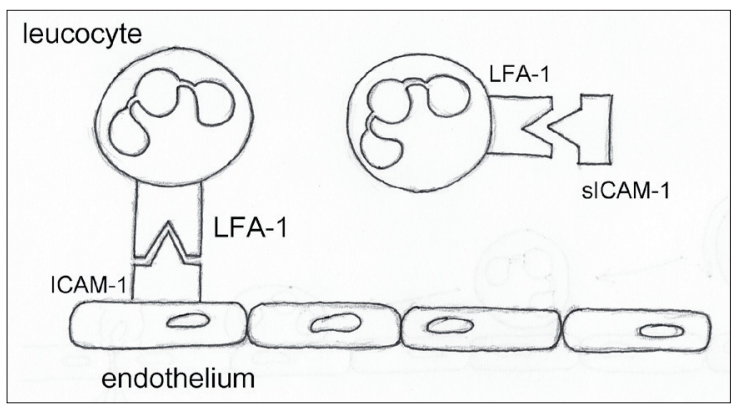

Figure 3. Opposite role of cell-bound (ICAM-1) versus soluble (sICAM-1) in leucocyte activation - saturation of LFA-1 on the leucocyte by sICAM-1 will prevent it from interaction with endothelium and further events (transmigration)

\section{Cell adhesion molecules in human}

\section{disease}

Cross-sectional studies first showed increased levels of CAMs in patients with diabetes mellitus complications such as retinopathy [3], nephropathy [4]. Fasching et al. [3] found increased levels of sICAM-1 and SVCAM- 1 but not s-ELAM in patients with insulin-dependent diabetes mellitus. In another study [6] the same authors found increased concentrations of sICAM, sVCAM and sELAM in subjects with non insulin dependent diabetes mellitus. Elevated levels of analyzed CAMs were strongly related with each other but not with the metabolic status (neither with $\mathrm{HgA} 1 \mathrm{c}$, glucose control nor insulin requirement) suggesting a mechanism which is independent from or at least not secondary to metabolic abnormalities. Schmidt et al. [4] observed increased sVCAM-1 in diabetic patients with nephropathy and microalbuminuria in comparison to those without this complication. In both above-mentioned studies the investigators postulated that the pathomechanism of retinopathy or nephropathy was related to angiopathy caused by endothelial damage and secondary vascular wall lesions independently from rheological, haemostatic or glycaemia control parameters.

\section{Cell adhesion molecules in nervous system pathology}

\section{Peripheral nervous system}

Based on the above findings and given that polyneuropathy is the most common complication of diabetes seen in

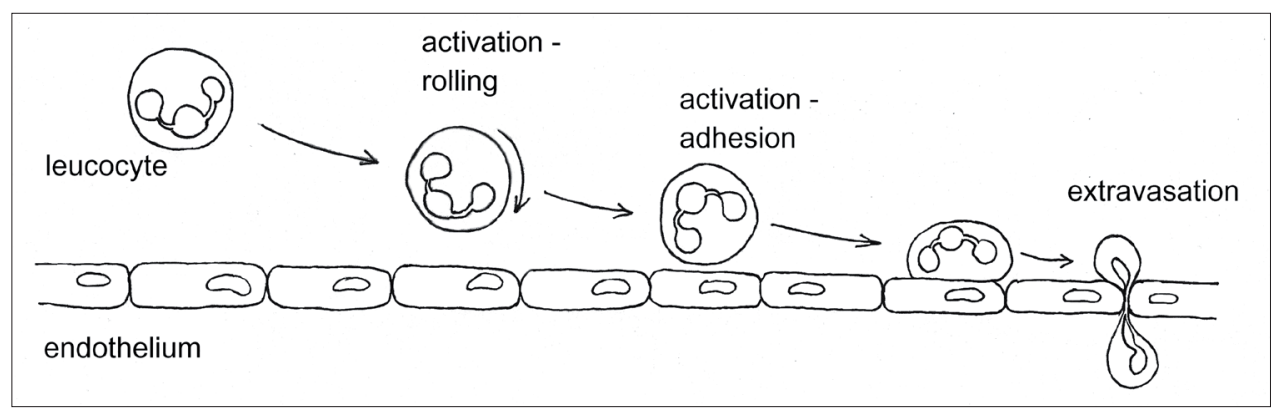

Figure 2. ICAM-1-mediated leucocyte interaction with endothelium 
more than one third of patients Jude et al. [5] showed that increased levels of E-selectin and P-selectin are important risk factors for and predict lesions of the peripheral nerves in patients with diabetes. They also found that P-selectin and ICAM-1 concentrations were increased in diabetic patients with neuropathy. Jude et al. also postulated intermediate participation of the micro/macroangiopathy in the process of the nerve damage independently from metabolic status.

\section{Central nervous system}

On the other hand there are studies reporting CAMs involvement in the pathologies of the central nervous system like multiple sclerosis (MS). Losy and Niezgoda [1] showed increased PECAM-1 in MS patients with gadolinium-enhancing lesions in comparison to patients with non-active lesions. They hypothesized direct involvement of PECAM-1 in the process of blood-brain barrier damage and secondary extravasation of leukocytes towards brain parenchyma. In another study Niezgoda and Losy [7] found decreased levels of sVCAM-1 in MS patients treated with steroids which correlated with clinical improvement suggesting direct participation of this molecule in the pathomechanism of the disease.

The same authors [8] found significantly decreased slCAM-1 levels in cerebrospinal fluid in MS patients after treatment with cladribine - a potent immunosuppressive drug. All of the above suggest that CAMs may be involved directly as well as indirectly in immune-mediated nerve damage and that they react to treatment and reflect the decrease in intensity of the pathological immune pathway.

Another cell adhesion molecule - neural cell adhesion molecule (NCAM-1) was analyzed in the study carried out by our group - Charles et al. [9]. In this study the investigators showed reappearance of the polysialylated form of NCAM (PSA-NCAM) on the surface of demyelinated axons within the plaques in the brains of MS patients in post-mortem immune-histochemical analysis. Physiologically PSA-NCAM is found only on immature axons. In neuron-glial myelinating in vitro cultures it has been observed (author's unpublished data) that PSA-NCAM gradually disappears from the surface of the axons as the myelination progresses - the oligodendrocyte processes seem to be capable of rolling around and myelinate the axons only at sites were PSA-NCAM has disappeared. This suggests that desialylation of NCAM might be one of the crucial neurolemma maturation point in time which permits the axon to be myelinated.

The authors of the mentioned study [9] hypothesized that the re-expression of PSA-NCAM may be a negative regulator for the process of remyelination. It could also be speculated however that its re-expression is on the contrary rather

Source of funding: This work was funded by the author's resources. Conflict of interest: The author declares no conflict of interests.

\section{References}

1. Losy J, Niezgoda A, Wender M. Increased serum levels of soluble PECAM-1 in multiple sclerosis patients with brain gadolinium-enhancing lesions. J Neuroimmunol 1999; 99(2): 169-172.

2. Xiao X, Mruk DD, Cheng CY. Intercellular adhesion molecules (ICAMs) and spermatogenesis. Human Reprod Update 2013; 19(2): 167-186.

3. Fasching P, Veitl M, Rohac $M$, et al. Elevated concentrations of circulating adhesion molecules and their association with microvascular complications in insulin-dependent diabetes mellitus. J Clin Endocrinol Metab 1996; 81: 4313-4317.

4. Schmidt AM, Crandall J, Hori O, et al. Elevated plasma levels of vascular cell adhesion molecule-1 (VCAM-1) in diabetic patients with microalbuminuria: a marker of vascular dysfunction and progressive vascular disease. Br J Haematol 1996; 92: 747-750.

5. Jude EB, Abbott CA, Young MJ, et al. The potential role of cell adhesion molecules in the pathogenesis of diabetic neuropathy. Diabetologia 1998; 41: 330-336.

6. Fasching E, WaldhäusI W, Wagner OE. Elevated circulating adhesion molecules in NIDDM - potential mediators in diabetic macroangidopathy. Diabetologia 1996; 39(10): 1242-1244. that somehow the reappearance of PSA-NCAM re-prepares

\section{NCAM in the peripheral nerve demyelination}

In the light of all the above Niezgoda et al. hypothesized that a similar process may take place in the peripheral nersignificantly increased sNCAM-1 concentrations in sera of patients with peripheral nerve demyelinating diseases like multifocal motor neuropathy, chronic demyelinating polypre Guillain-Barre syndrome in comparison to tory type (defined by respectively increased or normal CSF protein level) as well as in comparison to healthy controls. cal correlated with the severity of the clinidemyelination. sNCAM concentration was also increased in sera of patients with axonal polyneuropathies in comparison healthy subjects but less than in the group with peripheral strongly with myelin sheath damage and/or its repair events. NCAM might also be involved but to a lesser degree in axopathology (neurolemma damage?).

process of up-regulation of NCAM synthesis in the demyelinated axons/neurons. Given that NCAM is known to be a strong promoter of neurite outgrowth [11] it seems that the is as for the other CAMs the negative feedback mechanism limiting a possible uncontrolled axon outgrowth and possibly uncontrolled remyelination - sNCAM saturates the Our findings suggest that cell-bound form of NCAM cr be a strong promoter of myelination and its soluble form increased levels might be regarded rather as a marker of pemolecule eventually could be used to monitor the activity of the demyelinating process.

It is also likely that if NCAM involvement in the pe列 myelinating diseases of the peripheral nerves e.g. either by using monoclonal antibodies directed against the soluble Further studies are needed to confirm the above findings and hypotheses. a sign of the new maturation process of neurolemma and the neurolemma for the reception of the new oligodendropromoting its re-expression on the surface of the nerves or 
7. Losy J, Niezgoda A. The effect of treatment with steroids on sVCAM-1 in the CSF and sera of MS patients. J Neuroimmunol 1998; 90(1): 97-97.

8. Niezgoda A, Losy J, Mehta PD. Effect of cladribine treatment on beta-2 microglobulin and soluble intercellular adhesion molecule 1 (ICAM-1) in patients with multiple sclerosis. Folia Morphol 2001; 60(3): 225-228.

9. Charles P, Reynolds R, Seilhean D, et al. Re-expression of PSA-NCAM by demyelinated axons: an inhibitor of remyelination in multiple sclerosis? Brain 2002; 125(Pt. 9): 1972-1979.

10. Niezgoda A, Losy J, Michalak S, et al. Elevated sNCAM-1 concentrations in sera from patients with polyneuropathies. Neurology 2015; 84(14 Suppl.): P7.083.

11. Takei K, Chan TA, Wang FS, et al. The Neural Cell Adhesion Molecules L1 and NCAM-180 act in different steps of neurite outgrowth. J Neurosci 1999; 19(21): 9469-9479.

Address for correspondence:

Dr n. med. Adam Niezgoda

Department of Neurology

University of Medical Sciences of Poznan

ul. Przybyszewskiego 49

60-355 Poznan

Tel.: +48 606 459-290

E-mail: adamniezgoda@wp.pl

Received: 17.10.2015

Revised: 29.10.2015

Accepted: 29.10.2015 